Katarina Jovičić, $\mathbf{P h D}{ }^{*}$

Original scientific paper

UDC: 347.447 .6

doi: $10.5937 /$ spz0-20337

\title{
THE CONCEPT OF THE FUNDAMENTAL BREACH OF CONTRACT IN THE CISG
}

Abstract

When contracting party fails to perform the contract for the international sale of goods, then the other party can use certain remedies, including the right to terminate the contract. The termination of the contract in situation when the debtor has breached his contractual obligation opposes the principle pacta sunt servanda and all legal systems provide for the conditions and limitations under which creditor can acquire and realize that right. The most important limitation in that sense refers to the requirement that the breach of contract must be serious and severe.

The Vienna Convention on Contracts for the International Sale of Goods in this respect provides for the concept of fundamental breach of contract, as the general ground for termination the contract due to it's non-performance. General because it takes no account what exactly debtor do or not do when violated the contract; it is only important that his actions fits with the conditions for qualification the fundamental breach of contract. In that sense the Convention sets three criteria for estimate that question: first, that the debtor has breached the contract; second, it has resulted in such detriment to the other party as substantially deprives him of what he is entitled to expect under the contract and third, the debtor did not foresee such a damage as a consequence of breach of contract nor such a result could forese a reasonable person of the same kind in the same circumstances.

The concept of fundamental breach of contract is the original solution of the Vienna Convention and is the result of decades of work on the unification of the law of the international sale of goods. The most important achievement of such solution is that it introduced applicable objective criteria and standards for the evaluation of the significance and severity of the breach of the contract which are sufficient to activate the creditor's right to terminate it. Several decades of successful implementation of the Convention contributed to the developing of that concept in practice and to its increasingly application not only

\footnotetext{
* Research Fellow, Institute of Comparative Law, Belgrade, e-mail: k.jovicic@iup.rs.
} 
in other international sources of law for the contract of sale of goods, but also in significant number of national laws. On that way legal systems harmonize over time in relation to this question, which contributes to the simplification of trading on the international market and to economic development and prosperity.

Keywords: sale of goods, breach of contract, Vienna convention, the general ground for termination the contract due to its non-performance, concept of fundamental breach of contract.

\section{Introduction}

When a debtor fails to perform what he has accepted as his contractual obligation from a contract on the international sale of goods, then the other party may be able to use a certain legal remedies against him in order to restore the balance of mutual contractual benefits, which has been disrupted by the breach of the contract. These remedies include the right of the creditor to terminate the contract if other conditions as well, have been met. The termination of the contract is contrary to the principle of pacta sunt servanda and all legal systems set limits under which the creditor acquires or realizes that right, which is necessary to prevent its abuses, as well as to maintain and enforce as many contracts as possible. In this regard, in the comparative law, the view that the termination can only be achieved for the most serious violations of the contract prevails. Bearing in mind that it is impossible to precisely determine all such violations in advance, the issue of the conditions for acquiring the right to terminate contracts in legal sources is regulated by the special and by the general rules on a regular basis. The formulation of a general rule, which is appropriate for application to the situations not being covered by specific rules is not easy to achieve, and in comparative law, the concept of a fundamental breach of contract in the Vienna Convention on Contracts for the International Sale of Goods ${ }^{1}$ stands out as a good example (further: the Vienna Convention).

\footnotetext{
${ }^{1}$ The UN Convention on Contracts for the International Sales of Goods, Vienna 1980. The quality of the Vienna Convention's solution is clearly confirmed by the fact that it has been successfully applied for more than three decades and is taken over not only by international sources of contract law but also by an increasing number of national regulations. Thus, for example, UNIDROIT Principles of International Trade Contracts (UNIDROIT Principles), Principles of European Contract Law and Draft Common Frame of Reference (DCFR), similar to the concept of fundamental breach of contract in the Vienna Convention, provide the "essential non-performance" as basis for the termination of the contract (Art. 7.3.1. UNIDROIT Principles; Art. 8: 103 Principles of European contract law; Art. 3: 502 DCFR. In national regulations this concept has long been accepted in Scandinavian law, but also in Estonian Law of Obligations, The Netherlands Wetboek; Chinese Contract Law, and as an alternative proposal is also formulated in Art. 264. Draft of the Civil Code of the Republic of Serbia (text of May 29, 2015).
} 


\section{The determination of a fundamental breach of contract}

The rule on a fundamental breach of contract was set forth in Art. 25. of the Vienna Convention, which reads as follows: "A breach of contract committed by one of the parties is fundamental if it results in such a detriment to the other party, so as to substantially deprive him of what he is entitled to expect under the contract, unless the party in breach did not foresee and a reasonable person of the same kind in the same circumstances would not have foreseen such a result.". ${ }^{2}$

Based on what is previously exposed, there are three requirements that have to be met in order for one violation of the contract to be qualified as fundamental: first, that the debtor has violated the contract; second, that the other party suffer damage as consequence of the breach of contract, which essentially deprives him of what he was justifiably expected from the contract performance; third, that the party that committed the violation had foreseen the damage as its consequence, or that such a consequence could have been predicted by a reasonable person of the same characteristics given the same circumstances.

\subsection{Violation of the contract}

Legally valid contracts bind on the parties that concluded it and, most widely, any deviation from what was agreed represents a breach of contract. However, things cannot be simplified so much because there are many circumstances to be considered before it is concluded that the debtor has violated the contract in a way which is relevant from the legal point of view and give the creditor right to legal remedies. ${ }^{3}$ In the Vienna Convention, this issue has been regulated in accordance with the unitary concept of non-performance of the contract, which is characterized by the principle that any deviation from what the contract stipulates represents its non-performance ${ }^{4}$ The debtor's fault is not relevant to assessing whether a contract has been breached or to qualify one breach of contract as a

\footnotetext{
${ }^{2}$ On the origin of a provision on fundamental breach of contract in the Vienna Convention, see J. Perović, Bitna povreda ugovora - Međunarodna prodaja robe, Službeni glasnik SCG, Beograd 2004, 126-131.

${ }^{3}$ K. Jovičić, „Određenje pojma neizvršenja ugovora, s osvrtom na neizvršenje ugovora o prodaji robe”, Strani pravni život $1 / 2014,70$.

${ }^{4}$ In the case of a contract for the sale of goods, this may be a failure to fulfill any contractual obligation, both on the seller's side and on the buyer's side, regardless of the reason that led to it and irrespective of the fact whether the debtor had failed to performe the contract, or hadn't fulfilled it, as foreseen. This may also be a delay in the fulfillment of an obligation, partially fulfillment, or any other deviation from the agreed terms, including failure to fulfill the obligation to cooperate. Ibid., 71 .
} 
fundamental; it is significant only for determining the remedies available to the creditor. Thus, the fact that the debtor is excused from the contractual liability ${ }^{5}$ always prevents the creditor from claiming compensation, and if it becomes impossible to fulfill the obligation (which is also the basis for the exclusion from contractual liability), then he also loses the right to claim the specific performance. However, all other remedies, and thus the right to terminate the contract under the stipulated conditions, remain at his disposal.

\subsection{Detriment of a contractual interest}

In order for a breach of contract to be fundamental, it is necessary that the creditor has suffered damage and not just any damage, but only the damage which essentially deprives him of the benefit he justifiably expected from the contract and its performance. This question is assessed with regard to the interests of the injured creditor. The subjective criterion is primary, but it is not, however, exclusive nor should be because such a solution could be a source of abuse. For this reason, the rule requires that only the creditor's justified expectations are to be taken into account. In this regard, the degree of the vulnerability of his interests is primarily based on the assumption that the contract, in addition to regulating contractual obligations, also indicates the importance of the parties that have concluded it. Thus, for example, if the contract stipulates that delivery should be within a fixed period of time and the seller misses that deadline, then this fact itself is sufficient to constitute a fundamental breach of contract. In the same situation, however, without a fixed deadline, the breach of contract would not be so qualified.

Instead of the term "damages" in Art. 25. of the English text of the Vienna Convention, the term "detriment" is used, which is specific in a way that it is not usually used in other texts of the same kind, nor is it mentioned elsewhere in the Convention. Since the definition of "detriment" is not given in the text of the Vienna Convention, and in Art. 74., which regulates the notion of damage ${ }^{6}$ uses the term "damage", it is concluded that those are not an analogous terms. In relation to this issue in the literature prevails the view that the damage in the sense of Art. 25. of the Vienna Convention, i.e. as part of a substantive violation of the

\footnotetext{
${ }^{5}$ The issue of the exemption of a debtor from contractual liability is regulated by Art. 79. of the Vienna Convention. ${ }^{6}$ Art. 74. provides that the compensation for damages for the breach of contract consist of a sum equal to the loss, including loss of profit suffered by the other party.
} 
contract, has to be widely interpreted and that the concept of "damage" includes both actual and future monetary losses, as well as any other negative consequence in the form of material or non-pecuniary damage. ${ }^{7}$

Further, this damage must be such that it substantially deprives the party which is loyal to the contract of benefits that were expected from it. The emphasis is, therefore, on the effects that the damage, as a result of the breach of contract, has caused to the other contracting party ${ }^{8}$. That exactly is necessary to justify the claim for termination of the contract ${ }^{9}$ - that no other legal remedy in this situation would be adequate for the injured party. The fact that the Convention does not give a closer definition of the term "substantially" but to decide on it by court or arbitration according to the circumstances of the particular case, may cause problems in the application of the concept of the fundamental breach of contract due to the different interpretations of that term ${ }^{10}$.

\footnotetext{
7 The same: F. Ferrari, „Fundamental Breach of Contract Under the UN Convention on the International Sale of Goods - 25 Years of Article 25 CISG", Journal of Law and Commerce Vol. 25/2006, 495; M. Will, „Article 25”, in: Commentary on the International Sales Law, The 1980 Vienna Sales Convention (eds. C. M. Bianca and M. J. Bonell), Giuffrè, Milan 1987, 211.

${ }^{8}$ In this way, it is clearly pointed out that the decisive criterion is not reflected in the degree of damage, but in the significance of the interests that the contract and the specific contractual obligation had for the injured party. See J. Perović, 133. That does not exclusively depend on size of the damage, though the size of the damage is one of the important elements when determining the significante of the damage for the creditor. See U. Schroeter, „Art. 25”, in: Schlechtriem\&Schwenzer Commentary on the UN Convention on the Internatioinal Sale of Goods (CISG) (ed. I. Schwenzer), Oxford University Press, Oxford 2016, 428-429.

${ }^{9}$ This is assessed according to the circumstances of each case in particular. Thus, for example, if the seller fails to fulfill his obligation to pack goods, but the goods are delivered to the buyer properly, the damage in the sense of "detriment" exists if the circumstance precisely deprived the buyer of the possibility to sell goods to third parties (for example, the goods are recognizable by their packaging, which distinguishes them from goods of the same type of other manufacturers, which are of doubtful quality). P. Schlechtriem, Uniform Sales Law - The UN-Convention on Contracts for the International Sale of Goods, Manz, Wien 1986, 60 .

${ }^{10}$ In assessing this issue, the court or arbitration can be guided by previous court decisions and doctrinal attitudes. The Commentary of the UNCITRAL Secretariat can also be of great help which, in this regard, recommends that the following circumstances should be taken into account: the value of the entire contract, the monetary loss resulting from the breach of the contract, and to what extent the violation of the contract made by one party affects the other activities of the other contracting party. See: http://www.cisg.law.pace. edu/cisg/text/secomm/secomm-25.html (last accessed September 20, 2018). These guidelines, however, are given in the context of comments on Art. 23. of the Draft of the Convention of 1978, which has been amended to the final wording of Art. 25. of the Convention, and it should be taken into account with caution. The most complete change between the draft of the provision on a fundamental breach of contract and its final text is reflected in the fact that instead of the degree of damage, the emphasis was put on the importance of the interests that the contract and the specific contractual obligation had for the injured party. On the basis of this, it is concluded that the existence of a fundamental breach of contract can only be said in the event that that interest is brought into question, that is, only if the injured party loses interest in the contract being executed after his injuries have occurred. For details see P. Schlechtriem, Commentary on the UN Convention on the international Sale of Goods, Clarendon Press, Oxford 1998, 177.
} 
Here, the question of when the damage, that the creditor suffers from the breach of the contract, becomes such that it substantially deprives him of what he expects from the contract, is being raised. Pursuant to the provisions of Art. 25, it follows that this is the moment when the injured party has to prove that fact or that the breach of contract inevitably leads to that consequence. In the assessment of this issue, not only is the subjective interest of the injured party relevant, but also should be taking into account the expectations that are objective, first of all based on the provisions of the contract itself and on the circumstances of the particular case ${ }^{11}$.

\subsection{The predictability of the damages}

Finally, when it is established that the creditor suffered damage due to a breach of contract and that because of it he is substantially deprived of what he reasonably expected from its performance, then it still does not mean that a fundamental breach of contract has occurred. This is because the debtor has the right to prove that such a consequence he did not have foreseen, nor would a reasonable person of the same kind in the same circumstances have foreseen such a result. ${ }^{12}$ If he proves that with success, then there is no fundamental breach of contract, even if the qualification requirements for the damage are satisfied.

The question whether the damage could have been known to the party that violated the contract primarily depends on the circumstances of the particular case, but also on the personal ability of the debtor (for example, from his experience, from ability to perceive the circumstances of the matter in question, etc.) However, even here there was not only a subjective criterion but an objective criterion as a corrective, which is reflected in the "reasonable person of the same kind"13. An objective criterion is necessary because, otherwise, the party that violated the contract could always refer to the unforseeable circumstances i.e. to the unforseeable consequences of his actions, and that would be sufficient

\footnotetext{
${ }^{11}$ M. Will, 215.

${ }^{12}$ The second part of the sentence, Art. 25. The test of the predictability of damage is also the final condition for qualifying one breach of contract as fundamental. The justification of this additional filter is found in the need to balance the interests of both parties and in unusual, special circumstances. This contributes to the fact that a party, aware of the possible consequences of its failure to perform a contract, may not enter into a contract, or will take the necessary measures to prevent its non-performance. See Ibid., 215-216.

${ }^{13}$ Since the persons who conclude the contracts on the international sale of goods, as per the rule, are professional traders, the phrase "reasonable person" can also be understood as a "reasonable trader" or a person with the necessary skills to deal with the business.
} 
to prevent qualification of a breach of the contract as a fundamental one. That is why both criteria are interconnected and must be used together, since only in this way can the controversy be corrected. ${ }^{14}$

Here also raises the question in which moment the party that breached the contract, should anticipate the consequences of such conduct? Is it the moment when the contract is concluded, or a moment after that and if so, which one? Since the Vienna Convention does not provide the answer to this question, in the literature it is the source of various interpretations. Thus, while one group of authors considers that the moment of the conclusion of the contract ${ }^{15}$ is relevant, the others deem that it is the moment in which the contract is breached or the period immediately prior to that ${ }^{16}$, while professor Hannold states that the moment when creditor informe the other party that the breach of a contract cause him a fundamental damage should be considered as relevant ${ }^{17}$.

The above points of view would make sense if there had been made a mistake in the determination of the text of the Vienna Convention, due to which this essential issue remained unsettled. However, there is no real basis for such attitude, given that the history of work on the formulation of Art. 25 of the Convention shows that the proposal which explicitly states that the predictability of the damage is related to the moment of the conclusion of the contract, is not accepted. Based on this, it can be concluded that, by omitting any definition of the moment relevant to the assessment of predictability, the Vienna Convention actually wanted to enable courts and arbitrations to decide on the matter on the basis of a flexible norm, so that they can decide with respect to the circumstances

\footnotetext{
${ }^{14}$ Thus, for example, an experienced and wise trader can know more and predict better than the average person in his profession, and by applying a purely objective criterion, he could successfully oppose the qualification of a breach of contract made by him, as relevant. In this way, a real person would be able to hide behind the standard of an imaginary "reasonable person", and this is not what is desirable with this provision. See M. Will, 220.

${ }^{15}$ See more: R. Herber, B. Czervenka, Internationales Kaufrecht, Kommentar zu dem Übereinkommen der Vereinten Nationen vom 11. April 1980 über Verträge über den internationalen Warenkauf, Beck, München 1991, 87; P. Schlechtriem, 181; J. Perović, 160.

${ }^{16}$ M.Â.B. Soares y R.M.M. Ramos, Contratos internacionais: compra e venda, cláusulas penais, arbitragem, Almedina, Coimbra 1986, 128; J. D. Feltham, „The United Nations Convention on Contracts for the International Sale of Goods", Journal of Business Law 1981, 346.

${ }^{17}$ This notice should be given after the conclusion of the contract, but before its execution. Professor Hannold, in support of this view, also cites the case-law in which the court decided whether there was a substantial breach of contract because the seller did not pack the goods (rice) into the new bags, as the contract stipulated, nor was it done after the contract was concluded, but before the delivery, when the buyer informed him that he solely wanted the goods to be packaged in new bags, as only under this condition could they be sold to the third parties. J. Hannold, Uniform Law for International Sales under the 1980 United Nations Convention, Kluwer Law International, The Hague 1999, 209.
} 
of the particular case ${ }^{18}$. This, however, contributed to a legal uncertainty, which could have been avoided if a different solution was accepted, that is, if this issue was explicitly resolved by the Vienna Convention itself.

Of all the foregoing proposals it seems that it can be argued with the strongest arguments that the predictability of the damage should be related to the moment of the conclusion of the contract. Namely, if it turns out that the question of justified expectations from the injured party's contract is assessed by the moment of its conclusion (which has already been said in the consideration of the question of "Detriment of a contractual interest"), then the same principle can be applied also in relation to the predictability of the consequences of the injured contract. In other words, if the expectations of the contracting parties from the performance of the contract are formed at the time of its conclusion, then the consequences of the non-performance of the contract should also be foreseen at the same time. Any other solution that takes into account some other moment as relevant (which would necessarily be after the conclusion of the contract) leads to legal uncertainty, because the parties assume that the contract will be performed under the circumstances in which it was concluded and the question is, whether they at all conclude a contract if they knew that one of them would later require the change contractual obligation or one part of it.

\section{The burden of proving the predictability of damage in the context of a fundamental breach of contract}

The Vienna Convention in Art. 2 explicitly states that the party in breach has to prove that the damage was unpredictable if he wishes to challenge the creditor's assertion that the breach of the contract is fundamental. This rule does not cause any dilemma in situations when it is not disputable that the contractual obligation which had been violated, constitutes an essential element of the contract (for example, when the delivery time is fixed), as well as when the request is satisfied that a "reasonable person of the same characteristics in the same

\footnotetext{
${ }^{18}$ About this question see: Legislative History 1980 Vienna Diplomatic Conference and preparations for the Conference, CISG, Article 25, http://www.cisg.law.pace.edu/cisg/chronology/chrono25.html (last accessed September 20, 2018). Moreover, in Art. 74 concerning compensation for damages, the predictability of damage is explicitly related to the moment of the conclusion of the contract, unlike in Art. 25, and on the basis of this, it can be concluded that there was no intention that Art. 25 sets such a restriction.
} 
circumstances" would have predicted the nature of the injury done ${ }^{19}$. The issue is, however, more complex when a specific case is characterized by special, unusual circumstances, which the party that breached the contract did not know, and that such circumstances could not been known to a "reasonable person with the same characteristics", too. Under these conditions, the breach of contract cannot be qualified as fundamental. However, in the described situation, the injured creditor has the right to prove that he has notified the debtor in a timely and appropriate manner about the special circumstances, or that the debtor has been informed about those circumstances on the otherwise manner. This practically means that the injured party can also obtain the fundamental breach of contract in circumstances under which this would be difficult to achieve in the normal order of the things and actions. ${ }^{20}$

\section{Conclusion}

The conditions under which the violation of the contract's obligations may be qualified as a fundamental breach of contract set for in the Vienna Convention, clearly indicate that this legal source respects the principle of pacta sunt servanda and seeks to keep and enforce as many contracts as possible. The restriction for acquiring and using the right to terminate the contract due to its non-performance, imposed by the concept of a fundamental breach of contract and the rule of foreseeability, are in the interest of the debtor because, in this way, he gain an additional possibility for the contract to be executed. The predictability rule, however, is not at the expense of the injured party's interests, but its primary function is to limit the right for termination the contract to justified cases only, when other legal remedies, first of all, claim for damages, cannot adequately compensate for the losses that the creditor suffers from a non-performance.

However, a flexible formulation of the concept of a fundamental breach of contract means that a court or arbitration ultimately decides upon it on the basis of circumstancias of every particular case, which may lead to arbitrariness and legal uncertainty. Therefore, this concept carries a

\footnotetext{
19 "If, for example, when interpreting a contract, a particular understanding of a particular trade profession is found to be relevant, then the party that breached the contract cannot be relied upon its own ignorance. In order to avoid the termination of a contract on the basis of a fundamental breach of contract, the lack of personal knowledge of the parties in question is not sufficient; in order to challenge the existence of a fundamental breach of contract, such a defect should exists, both on the party that committed the injury and on the side of a reasonable person of the same characteristics in the same circumstances." J. Perović, 163. ${ }^{20}$ Ibid., 164.
} 
special risk for the injured party, which is reflected in the fact that he cannot know in advance whether the breach of the contract made by the debtor is fundamental, i.e. whether he can terminate the contract on that basis. In order to avoid this risk, the injured creditor will often use another legal remedy, which may be less appropriate to him. These uncertainties can be reduced only if the parties to the contract clearly and precisely compile their contract, in which the obligations and their significance are determined so that the need for interpretation is reduced to the minimum. However, the practice of applying the Vienna Convention, as well as the expert and scientific papers on the fundamental breach of contract, undoubtedly positively influence the overcoming of these uncertainties. In support of this goes the fact that the concept of a fundamental breach of contract is accepted by other international instruments for unification of the contract law, as well as fact that the number of national laws which opt for it constantly increase.

\section{References}

Feltham, J. D. „The United Nations Convention on Contracts for the International Sale of Goods", Journal of Business Law (1981).

Ferrari, F., „Fundamental Breach of Contract Under the UN Convention on the International Sale of Goods - 25 Years of Article 25 CISG", Journal of Law and Commerce, Vol. 25/2006.

Hannold, J., Uniform Law for International Sales under the 1980 United Nations Convention, Kluwer Law International, The Hague 1999.

Jovičić, K., „Određenje pojma neizvršenja ugovora, s osvrtom na neizvršenje ugovora o prodaji robe", Strani pravni život, 1 /2014.

Perović, J., Bitna povreda ugovora - Međunarodna prodaja robe, Službeni list SCG, Beograd 2004.

Rolf, H., Czervenka, B., Internationales Kaufrecht, Kommentar zu dem Übereinkommen der Vereinten Nationen vom 11. April 1980 über Verträge über den internationalen Warenkauf, Beck, München 1991.

Schlechtriem, P., Commentary on the UN Convention on the international Sale of Goods, Clarendon Press, Oxford 1998.

Schlechtriem, P., Uniform Sales Law - The UN-Convention on Contracts for the International Sale of Goods, Manz, Wien 1986.

Schroeter, U., „Art. 25”, in: Schlechtriem \& Schwenzer Commentary on the UN Convention on the Internatioinal Sale of Goods (CISG), (ed. Ingeborg Schwenzer), Oxford University Press, Oxford 2016.

Soares, M. Â. B., Ramos, R. M. M., Contratos internacionais: compra e venda, 
cláusulas penais, arbitragem, Almedina, Coimbra 1986.

Will, M., „Article 25”, in: Commentary on the International Sales Law, The 1980

Vienna Sales Convention, (eds. Cessare Massimo Bianca and Michael Joachim Bonell), Giuffrè, Milan 1987.

\title{
Legal sources
}

The UN Convention on the Contracts for the International Sale of Goods, 1980. https://www.cisg.law.pace.edu/cisg/text/treaty.html.

The UNIDROIT Principles of International Commercial Contracts, 1994. https:// www.trans-lex.org/400120.

The Principles of European Contract Law, 1995, 1997, 2003. https://www:translex.org/400200.

\section{Website references}

Legislative History 1980 Vienna Diplomatic Conference and preparations for the Conference. http://www.cisg.law.pace.edu/cisg/chronology/ chrono25.html.

\section{Dr Katarina Jovičić}

Naučni saradnik, Institut za uporedno pravo, Beograd

\section{KONCEPT BITNE POVREDE UGOVORA U BEČKOJ KONVENCIJI O UGOVORIMA O MEĐUNARODNOJ PRODAJI ROBE}

\author{
Rezime
}

Kada ugovorna strana propusti da izvrši svoju obavezu iz ugovora o međunarodnoj prodaji robe, onda druga strana stiče pravo na određena pravna sredstva, uključujući i pravo da ugovor raskine. Raskid ugovora $\mathrm{u}$ toj situaciji suprotstavlja se načelu pacta sunt servanda i svi pravni sistemi predviđaju uslove i ograničenja pod kojima poverilac to pravo stiče, odnosno može da koristi. Najvažnije organičenje u tom smislu je zahtev da povreda ugovora mora biti ozbiljna i teška. 
Bečka konvencija o ugovorima o međunarodnoj prodaji robe $\mathrm{u}$ odnosu na ovo pitanje predviđa koncept bitne povrede ugovora kao opšti razlog za raskid ugovora zbog neispunjenja. Opšti zato što se primenjuje nezavisno od toga šta je dužnik tačno učinio, odnosno nije uradio kada je ugovor povredio; bitno je samo da njegovo postupanje može da se kvalfikuje kao bitna povreda ugovora. U tom smislu Konvenicja postavlja tri kriterijuma na osnovu kojih se procenjuje to pitanje: prvo, da je dužnik povredio ugovor; drugo, da je time prouzrokovao takvu štetu drugoj ugovornoj strani da je ona izgubila mogućnost da ostvari svoja očekivanja od ugovora; i treće, da je dužnik predvideo takvu štetu kao posledicu povrede ugovora ili da bi takvu štetu predvidelo drugo razumno lice istih sposobnosti u istim uslovima.

Koncept bitne povrede ugovora je originalno rešenje Bečke konvencije i rezultat je decenijskog rada na unifikaciji prava međunarodne prodaje robe. Njeno najvažnije dostignuće u pogledu ovog rešenja je $\mathrm{u}$ tome što ono uvodi primenjive objektivne kriterijume i standarde za evaluaciju značaja i težine povrede ugovora, koja je dovoljna da aktivira poveriočevo pravo da ugovor raskine. Skoro 40 godina uspešne primene Konvencije širom sveta doprinelo je razvoju ovog koncepta u praksi i njegovoj sve široj primeni jer ga prihvataju ne samo međunarodni izvori prava za ugovor o međunarodnoj prodaji robe, već i sve veći broj nacionalnih prava. Na taj način se pravni sistemi vremenom harmonizuju $\mathrm{u}$ odnosu na ovo pitanje, što doprinosi pojednostavljenju trgovine na međunarodnom tržištu i ekonomskom razvoju i blagostanju.

Ključne reči: prodaja robe, povreda ugovora, Bečka konvencija, opšti osnov za raskid ugovora zbog neizvršenja, koncept bitne povrede ugovora. 